\title{
Koulutuksen kehittämisestä elinikäisen oppimisen edistämiseen
}

\begin{abstract}
Elinikäisestä jatkuvasta kasvatuksesta koulutusjärjestelmän suunnitteluperiaatteena on meillä keskusteltu 1960-luvulta lähtien. Keskustelu sai alkunsa Unescon vuonna 1965 julkaisemasta elinikäistä kasvatusta käsittelevästä muistiosta. Siinä hahmoteltiin laaja-alaisesti elinikäisen kasvatuksen järjestelmää ja sen suunnittelun peruslähtökohtia. Raportissa suositeltiin elinikäisen kasvatuksen huomioon ottamista kansallisten kasvatusjärjestelmien kehittämisessä.
\end{abstract}

Suositus sai laajalti vastakaikua eri puolilla maailmaa ja siihen suhtauduttiin myönteisesti täällä Suomessakin. Suomen Unesco-toimikunta ja Tampereen yliopiston aikuiskasvatuksen laitos järjestivät vuonna 1968 kaksipäiväisen "Elämänikäisen kasvatuksen symposiumin", johon osallistui noin 50 henkilön joukko tuon ajan keskeisiä vaikuttajia. Seuraavana vuonna ilmestynyt Vapaan sivistystyön vuosikirja XVI koottiin pääosin symposiumin alustuksista. Se sisälsi myös mm. suomenkielisen version edellä mainitusta Unescon muistiosta. Elinikäisen kasvatuksen ajatus levisi vähitellen sekä laajan yleisön että koulutuspoliittisten päättäjien tietoisuuteen.

Vuonna 1969 ilmestyneessä Koulutusrakennekomitean mietinnössä nähtiin "jatkuvan koulutuksen" järjestäminen eräänä 1970-luvun koulutuspolitiikan päätehtävänä. Mainittakoon, että myös opiskelijat olivat aktiivisesti kehittelemässä tätä uutta koulutuksen kehittämisstrategiaa. SYL järjesti vuonna 1971 valtakunnallisen Jatkuvan kasvatuksen konferenssin, jossa oli mukana kotimaisten asiantuntijoiden lisäksi myös Unescon edustaja.

Jatkuvan kasvatuksen tai jatkuvan koulutuksen periaate - kuten opetusviranomaiset ja koulutussuunnittelijat sitä nykyisin nimittävät - vaikutti luonnollisesti myös Aikuiskoulutuskomitean työskentelyyn ja ehdotuksiin. Periaate kirjattiin valtioneuvoston vuonna 1978 antamaan aikuiskoulutuksen kehittämisen periaatepäätökseen. Vuonna 1982 opetusministeriö asetti toimikunnan selvittämään, millaisia vaatimuksia jatkuvan koulutuksen periaate asettaa maamme koulutusjärjestelmälle pitäen erityisesti silmällä aikuiskoulutuksen kehittämistarpeita. Toimikunnan työtä jatkoi edelleen jatkuvan koulutuksen projektiryhmä, joka esitti vuonna 1986 ilmestyneessä muistiossaan konkreettisen suunnitelman ehdotusten toteuttamiseksi. Projektiryhmä ehdotti mm., että valtioneuvoston pitäisi tehdä uusi periaatepäätös, jossa todettaisiin, että jatkuvan koulutuksen periaatetta tulee soveltaa koko koulutusjärjestelmän, eikä vain aikuiskoulutuksen kehittämiseen. Ehdotuksen toteutuminen kesti kuitenkin useita vuosia.

Valtioneuvoston vuonna 1990 eduskunnalle antamassa koulutuspoliittisessa selonteossa todetaan yksiselitteisesti, että jatkuvan koulutuksen periaate koskee koko koulutusjärjestelmää ja koko väestöä. Tämän mukaisesti Suomen koulutusjärjestelmää tulee kehittää niin, että jokaisella ihmisellä on kaikkina ikäkausinaan mahdollisuudet oman persoonallisuutensa jatkuvaan, monipuoliseen kehittämiseen järjestelmällisen ja joustavan opetuksen avulla.

Periaatteen hyväksymisestä on tietysti pitkä matka käytännön toteuttamiseen. koulutusjärjestelmän tai oppimisjärjestelmien kehittämisessä. Edellinen lähestyy 
kehittämistä yhteiskunnan koulutustarpeiden, jälkimmäinen yksilön oppimistarpeiden näkökulmasta. Meillä kehittämistyö on ollut tähän saakka ensisijaisesti koulutusjärjestelmän, aikuiskasvatuksessa erityisesti ammatillisten tutkintojen kehittämiseen keskittynyttä. Koulutusviranomaiset ja -suunnittelijat näyttävät ajattelevan, että jatkuvan koulutuksen periaate tarkoittaa vain normaalimuotoisen tutkintojärjestelmän siirtämistä - hiukan sitä soveltaen aikuisille. Kuten Sarala toisaalla tässä lehdessä toteaa, tavanomainen koulutus määriteltyine tavoitteineen ja sisältöineen sopii parhaiten tilanteisiin, joissa muutosnopeus on melko hidasta ja ennustettavaa. Nykyinen tilanne on juuri päinvastainen. Vaikka tutkintojärjestelmän kehittäminen aikuisten ammatillisessa peruskoulutuksessa on varmaan paikallaan, niin muilta osin tutkintojärjestelmän laajentamiseen aikuiskasvatuksessa täytyy suhtautua kriittisesti.

Hierarkisen ja kaiken kattavan tutkintojärjestelmän sijasta olisi nyt ryhdyttävä kehittämään yhteiskunnan nykyisten toimintamuotojen yhteyteen ja sisälle oppimisjärjestelmiä, jotka ovat joustavia ja paremmin ajan tasalla olevia. Niiden avulla voidaan vastata nopeammin yhteiskunnan muutoksesta aiheutuviin uusiin haasteisiin niin työ- kuin muussakin yhteiskuntaelämässä. Esimerkiksi työelämän kehittämistä tutkineet sosiologit ja psykologit ovat jo jonkin aikaa vaatineet työpaikkojen kehittämistä oppimisyhteisöiksi. He ovat myös laatineet luetteloita niistä vaatimuksista, mitä työn kehittäminen tähän suuntaan edellyttää. Oppiminen pitäisi siis liittää osaksi niin työtä kuin kaikkea muutakin yhteiskunnallista toimintaa. Ainakin aikuiskasvatuksessa tulisi pyrkiä eroon erillisistä koulutustilaisuuksista niin pitkälle kuin mahdollista.

Myös nuorisoasteen koulutuksen ja muun yhteiskunnan välisiä suhteita pitäisi lähentää tuntuvasti.

Muualla maailmassa on jo pitkälti omaksuttu koulukeskeistä ajattelua avarampi ja kokonaisvaltaisempi näkemys elinikäisestä oppimisesta ja sen edistämisestä yhteiskunnassa. Iskusanoina ovat toimineet $\mathrm{mm}$. sellaiset termit kuin itseohjattu oppiminen (self-directed learning), oppimissopimukset (learning contracts), informaali ja satunnaisoppiminen (informal and incidental learning), työelämän laatu -liike (QWL, The quality of working life movement), reflektiivinen oppiminen (reflection and learning) jne. Kaikissa näissä lähestymistavoissa on kysymys yksilön/yksilöiden oppimisen tutkimisesta ja edistämisestä luonnollisissa toimintatilanteissa. Tutkijoiden mielenkiinto on siis nykyisin entistä enemmän käytännön toiminnan yhteydessä tapahtuvassa opiskelussa ja oppimisessa, ei niinkään koulutustilaisuuksien oppimistulosten selvittelyssä. Meillä tähän suuntaan on edetty $\mathrm{mm}$. eksperttiyden kehittymistä koskevissa tutkimuksissa, laatupiirejä oppimisympäristönä tarkastelleissa tutkimuksissa sekä kehittävän työntutkimuksen projekteissa. Tällainen lähestymistapa vaatii kasvatusalan tutkijoilta tiivistä yhteistyötä eri alojen tutkijoiden sekä kehittämistyössä mukana olevien henkilöiden kanssa. Alan koulutuksessa pitäisi opiskelijoille antaa laaja-alainen näkemys elinikäisestä oppimisesta ja valmiudet osallistua sen edistämiseen yhteiskunnan eri organisaatioissa.

Vaikka jatkuvan koulutuksen periaate on hyväksytty meillä koko koulutusjärjestelmän kehittämistrategiaksi, niin alaan liittyvä tutkimus on ollut toistaiseksi vähäistä. Tätä puutetta poistamaan käynnisti Suomen Akatemia vuoden 1989 lopulla kolmivuotisen "Jatkuvan koulutuksen tutkimusohjelman". Akatemian tarkoituksena on lisätä ohjelman avulla jatkuvan koulutuksen tematiikkaan kohdistuvaa tieteellistä tutkimusta sekä parantaa tutkimuksellisen panoksen hyväksikäyttöä viranomaisten päätöksenteossa. Nähtäväksi jää, miten näissä tavoitteissa onnistutaan. Joka tapauksessa on selvää, että jatkuvan kasvatuksen problematiikka tarjoaa haasteellisen tutkimusalueen kaikille oppimisesta ja kehittymisestä kiinnostuneille tutkijoille. 